\title{
Reproductive cycle and embryonic development of the gastropod Melampus coffeus (Linnaeus, 1758) (Ellobiidae) in the Brazilian Northeast
}

\author{
Maia, RC. ${ }^{a *}$, Rocha-Barreira, $C A .^{b}$ and Coutinho, R. $^{c}$ \\ áLaboratório de Ecologia de Manguezais, Instituto Federal de Educação, Ciência e Tecnologia do Ceará, \\ Campus Acaraú, Av. Desembargador Armando de Sales Louzada, s/n, CEP 62580-000, Acaraú, CE, Brazil \\ 'Laboratório de Zoobentos, Instituto de Ciências do Mar, Universidade Federal do Ceará - UFC, \\ Av. Abolição, 3207, Meireles, CEP 60165-081, Fortaleza, CE, Brazil \\ 'Laboratório de Bioincrustação e Ecologia Bêntica, Departamento de Oceanografia, \\ Instituto de Estudos do Mar Almirante Paulo Moreira, Rua Kioto, 253, CEP 28930-000, Arraial do Cabo, RJ, Brazil \\ *e-mail: rafaelacmaia@yahoo.com.br
}

Received October 3, 2011 - Accepted January 25, 2012 - Distributed November 30, 2012

(With 4 figures)

\begin{abstract}
Melampus coffeus belongs to a primitive group of pulmonate mollusks found mainly in the upper levels of the marine intertidal zone. They are common in the neotropical mangroves. Little is known about the biology of this species, particularly about its reproduction. The aim of this study was to 1) characterize the morphology and histology of M. coffeus' gonad; 2) describe the main gametogenesis events and link them to a range of maturity stages; 3 ) chronologically evaluate the frequency of the different maturity stages and their relation to environmental factors such as water, air and sediment temperatures, relative humidity, salinity and rainfall; and 4) characterize M. coffeus' spawning, eggs and newly hatched veliger larvae. Samples were collected monthly between February, 2007 and January, 2009 from the mangroves of Praia de Arpoeiras, Acaraú County, State of Ceará, northeastern Brazil. The characterization of the gonad development stages was carried out using routine histological techniques. The results of this study show that Melampus coffeus is a simultaneous hermaphrodite. The follicles have masculine and feminine elements, interleaved within the gonad. M. coffeus presents a well-defined synchronous reproductive cycle, showing successive maturation, release and resting periods. The average diameter of the oocytes was negatively correlated with salinity and positively correlated with rainfall. The results show that no reproductive activity occurs during periods of drought. After the dry season, the increasing rainfall levels and reduced salinity lead to the appearance of very dense populations, predominantly composed of small individuals.
\end{abstract}

Keywords: hermaphroditism, histology, mangrove, pulmonata, reproduction.

\section{Ciclo reprodutivo e desenvolvimento embrionário do gastrópode Melampus coffeus (Linnaeus, 1758) (Ellobiidae) no Nordeste do Brasil}

\begin{abstract}
Resumo
Melampus coffeus encontra-se em um grupo primitivo de moluscos pulmonados, primordialmente marinhos, habitantes dos níveis superiores da zona entremarés, comum em manguezais do Oceano Atlântico. Pouco se sabe sobre a biologia da espécie, em especial, sobre a sua reprodução. Os objetivos deste trabalho foram: 1) caracterizar morfo-histologicamente a gônada de $M$. coffeus; 2) descrever os principais eventos da gametogênese e associá-los a uma escala de estágios de maturidade; 3) avaliar temporalmente a frequência dos estágios de maturidade e sua possível relação com os fatores ambientais, como a temperatura da água, do ar e do sedimento, a umidade relativa, a salinidade e a pluviosidade, e 4) caracterizar a postura, os ovos e a véliger recém-eclodida de $M$. coffeus. Foram realizadas coletas mensais de fevereiro de 2007 a janeiro de 2009, no manguezal da Praia de Arpoeiras, município de Acaraú-Ceará, na Região Nordeste do Brasil. A caracterização das fases de desenvolvimento da gônada foi realizada utilizando-se técnicas histológicas de rotina. Os resultados deste estudo mostram que Melampus coffeus é um hermafrodita simultâneo. Os folículos apresentam elementos masculinos e femininos, distribuindo-se na gônada intercalados radialmente. M. coffeus apresenta um ciclo reprodutivo sincrônico bem definido, evidenciando-se períodos sucessivos de amadurecimento, de liberação e de repouso. O diâmetro médio dos oócitos apresentou correlação negativa com a salinidade e positiva com a pluviosidade. Os resultados indicam que, nos períodos de estiagem, não há atividade reprodutiva. Após essa estação, quando os valores de pluviosidade aumentam e a salinidade diminui, as populações são bastante densas e predominam indivíduos pequenos.
\end{abstract}

Palavras-chaves: hemafroditismo, histologia, manguezal, pulmonata, reprodução. 


\section{Introduction}

The Ellobiidae family is a primitive group of pulmonate mollusks (Martins, 1996a, b). The ecology and physiology of these organisms have attracted great interest as they represent the transition between marine and land mollusks; they are probably the most primitive living group of Pulmonata and thus their study is key to understanding the evolution of the Gastropoda (Morton, 1955a, b; Martins, 1996a, b, 2001). These organisms show a combination of primitive reproductive features, such as their dependence on water for reproduction and hermaphroditism, together with advanced features such as genitalia with two separate gonadal ducts to avoid self-fertilization, a feature that confers selective advantages to these animals, making them one of the most successful groups of mollusks (Morton, 1955a, b).

Within this family, we can highlight the snails of the genus Melampus: these macrodetritivores feed on plant debris, preferably from mangrove leaves, and that makes them an important component of the food chain in neotropical ecosystems (Proffitt et al., 1993; Proffitt and Devlin, 2005). Melampus coffeus (Linnaeus, 1758) (Ellobiidae) is a common species in mangroves and marshes of the Atlantic Ocean and can be found from Florida to Uruguay (Rios, 1994). In many regions, it is the main macrodetritivore species, responsible for the degradation of most organic matter that will be subsequently exported to adjacent ecosystems (Mook, 1986; McKee and Faulkner, 2000). However, little is known about the biology of this species, particularly about its reproduction. There is no up-to-date and proven information allowing us to make generalizations of any kind.

Thus, the goals of this study were 1) to characterize the morphology and histology of Melampus coffeus' gonads; 2) to describe the main gametogenesis events and link them to a range of maturity stages; 3 ) to chronologically evaluate the frequency of the different maturity stages and their relation to environmental factors such as water, air and sediment temperatures, relative humidity, salinity and rainfall; and 4) to characterize $M$. coffeus's spawning, eggs and newly hatched veliger larvae.

\section{Material and Methods}

\subsection{The studied region}

To study the reproductive cycle and embryonic development of $M$. coffeus, specimens were sampled in the mangroves of Praia de Arpoeiras, Acaraú County, State of Ceará, Brazil ( $02^{\circ} 50$ ' $17^{\prime \prime} \mathrm{S}$ and $\left.40^{\circ} 04^{\prime} 56^{\prime \prime} \mathrm{W}\right)$. According to Köppen's classification (1948), the coastal climate type is defined as AW - rainy, tropical, hot and humid, with rains concentrated in the summer and autumn. The variation of the average monthly temperature does not reach $2{ }^{\circ} \mathrm{C}$, indicating a thermal stability. Regarding rainfall, the period with the largest rains spans from January to May and has monthly levels above $100 \mathrm{~mm}$ and reaching its peak in March with average rainfall levels of almost $380 \mathrm{~mm}$.

\subsection{Methodology}

Thirty specimens of $M$. coffeus were collected by hand every month from February, 2007 to January, 2009, totaling 720 analyzed individuals throughout this period. The samples were collected during daytime syzygy tides. Water, air and sediment temperatures and relative humidity were recorded in the field with the help of a thermo-hygrometer (Incoterm); local salinity was measured with a refractometer (Instrutherm, model RTS-101 ATC). Rainfall data were obtained from the FUNCEME - Fundação Cearense de Meteorologia e Recursos Hídricos.

The sampled animals were taken to the laboratory alive and each individual had its shell height measured with a caliper (accuracy $=0.01 \mathrm{~mm}$ ) and was weighed on a precision scale. The snails were anesthetized in a solution of seawater from the study area and $4 \%$ magnesium chloride for two hours. After full relaxation, verified by the absence of retraction to touch, the soft part was removed from the shell and fixed in saline Bouin's solution, where they remained for eight hours. After the fixation period, the sample was washed in running water several times and the gonad was removed and preserved in ethanol $70 \%$. The gonads were morphologically characterized and their macroscopic features, such as changes in the size and color, were recorded.

Routine procedures were applied for the histological analysis. The specimens were submitted to dehydration with alcohol, diafanization with xylene and embedded in paraffin. Longitudinal sections with $5 \mu \mathrm{m}$ were cut using a manual microtome knife and steel blade. Upon completion of the microtome slicing, the sections were stained with Harris hematoxilin and eosin (HE) and permanent slides were obtained with synthetic resin. Based on the microscope observations, the germinal cells were described and the gonadal development stages were identified. To estimate the growth of female cells throughout the study period, the diameters of about 200 female cells were measured each month. The diameter corresponded to the longest axis of each oocyte, only considering cells with a clearly visible nucleus.

During the study of the species' reproductive cycle, adult specimens $(19.67 \pm 0.99 \mathrm{~mm})$ were collected when spawning was observed in the field, and then were taken to the laboratory and kept in trays until spawning. Mangrove sediments from the same mangrove site were placed on the trays, together with mangrove leaves so as to provide abundant food for the animals. The trays were irrigated every day with water with a salinity of $32 \mathrm{ppt}$, which was the approximate salinity found in the studied area during the study period. We also used the same substrate the eggs were attached to in the field.

Twenty-seven egg masses were obtained from the laboratory, out of which ten were separated for egg counting and description while the others were kept in aquaria with aerated filtered water from the mangrove until the hatching of the larvae. Each mass of eggs was 
individualized and placed in a separate acrylic tank fitted with a cover with a $0.3 \mathrm{~mm}$-wide mesh at its center. Factors such as salinity $(32 \mathrm{ppt})$ and temperature $\left(28^{\circ} \mathrm{C}\right)$ were monitored daily. All egg masses were observed every day with a stereomicroscope and the overall condition of the eggs and the size and activity of the embryo inside the egg were recorded. Based on these observations, the development stages were characterized. We also determined the duration of each development stage, as well as the overall development time and the size of the embryo.

The Kruskal-Wallis non-parametric test was used in order to test for differences in the diameter of the observed cells, between the different developmental stages and between the months of sampling. The a posteriori multiple comparisons test was used to identify any significant differences $(\mathrm{p}<0.05)$. Spearman's nonparametric correlation analyses were performed in order to compare the gonadal development stages of $M$. coffeus (sexual inactivity, cell proliferation, cell differentiation, release and exhaustion) and the diameter of the female germinal cells with shell height, weight and abiotic parameters (temperature, salinity, rainfall and humidity).

\section{Results}

\subsection{Characterization of internal and external gonad's morphology}

M. coffeus most apical organ is the ovotestis, fitting under the apex of the shell and covering the digestive gland. It has a flat, tapered and hollow format. The germinal epithelium of the gonad consists of a cluster of follicles and features a transparent limestone inclusion within the cells of the connective tissue surrounding it.

During the reproductive phase, these follicles have an orange color with dark brown pigments and the size of the gonad increases considerably. In the period of sexual inactivity, the ovotestis is reduced and appears as a dark brown "small scar". This very same pattern was observed in juveniles.

The production of male and female gametes is concurrent, thus featuring a simultaneous hermaphroditism. The follicles have male and female elements, radially interspersed within the gonads. The maturation of sex cells occurred from the periphery to the lumen of the follicle.

\subsection{Characterization of $M$. coffeus gonad development stages}

We describe the following gonadal development stages:

I) "Resting" stage (Figure 1a)

This stage is characterized by the lack of follicles. It usually occurs in young specimens that have not started any reproductive activity or in organisms that have already passed through the gamete release period. In the latter case, there are follicular remnants scattered in the visceral mass. After reproduction, the ovotestis slowly starts to recover, yet the maturation process will only be resumed in the next reproductive event. The size of $M$. coffeus specimens in this phase ranged between $6.3 \mathrm{~mm}$ and $22.37 \mathrm{~mm}$, while the mean shell height was $16.51+3.3 \mathrm{~mm}(\mathrm{n}=176)$.

\section{II) "Cell Proliferation" stage (Figure 1b)}

During this period, the follicles begin to organize and are distributed in the visceral mass, filled with a significant quantity of small cells uniform in size, which makes its differentiation impossible. These elements are proliferating cells (oogonia or spermatogonia) and may be arranged in peripheral layers, emptying the central lumen, or completely filling the intrafollicular space. It marks the beginning of the maturation of the germ cells. In this stage, the snails have a mean size of $18.55 \pm 2.42 \mathrm{~mm}(\mathrm{n}=71)$, with the smaller ones measuring $12.9 \mathrm{~mm}$ and largest $23.34 \mathrm{~mm}$.

III) "Cell Differentiation/Maturation" stage (Figure 1c)

This stage is characterized by the fact that the follicles occupy the entire visceral mass, they are well organized and radially distributed. The follicular wall is composed of a single layer of cells and their nuclei are barely visible. The spermatogonia and spermatocytes featuring the initial spermatic stages could be observed, while spermatozoids may appear in the lumen. In the female follicles, an increase in the size of oocytes could be seen due to the accumulation of nutrients. During this period, the longest shell was $22 \mathrm{~mm}$ in height and the shortest $14.41 \mathrm{~mm}$, while the mean shell height was $18.60+2.14 \mathrm{~mm}(\mathrm{n}=41)$.

IV) "Final Maturation/Release" stage (Figure 1d)

In this stage, there are large quantities of ripe oocytes or spermatozoids in the lumen and along the follicles. The mature germinal cells always appear together with the germinal lineages of the opposite sex at various development stages. When mature male and female cells are found in the gonads, the oocytes occupy a peripheral position while the spermatozoids occupy the follicular lumen. The production of macrophages is intense in this stage, appearing as granules composed of a translucent yellow substance in the epithelium of the follicles or scattered in the visceral mass, becoming even more abundant with the release of the gametes or when the reproductive activity is to be restarted. In this stage, large spaces within the center of the follicles can also be observed due to the release of the gametes. The proliferation of new elements may occur even during the release of gametes. The mean shell size of $M$. coffeus during this stage was $18.34 \pm 2.34 \mathrm{~mm}$ $(\mathrm{n}=221)$, ranging from 11.41 to $22 \mathrm{~mm}$.

V) "Exhaustion" stage (Figure 1e)

At this stage, there is a full release of gametes. Remaining oocytes in a process of atresia and/or cell resorption and dispersed spermatozoid fragments may be found. At this stage, the larger individuals had $22.2 \mathrm{~mm}$ and the smaller ones $11.2 \mathrm{~mm}$ (mean $17.69+2.67 \mathrm{~mm}(\mathrm{n}=211)$ ).

\subsection{The reproductive cycle}

We observed the gonadal development cycle of the sampled M. coffeus specimens (Figure 2) in two different seasons: the first from February to July, 2007 and the second from March to June 2008, both comprising the "Final Maturation/Release" of gametes stage, i.e. M. coffeus reproductive period. We could see peaks of activity in February, 2007 and March, 2008, when 93.3\% and $86.7 \%$ of the specimens, respectively, were in the Final "Maturation/Release" stage. 

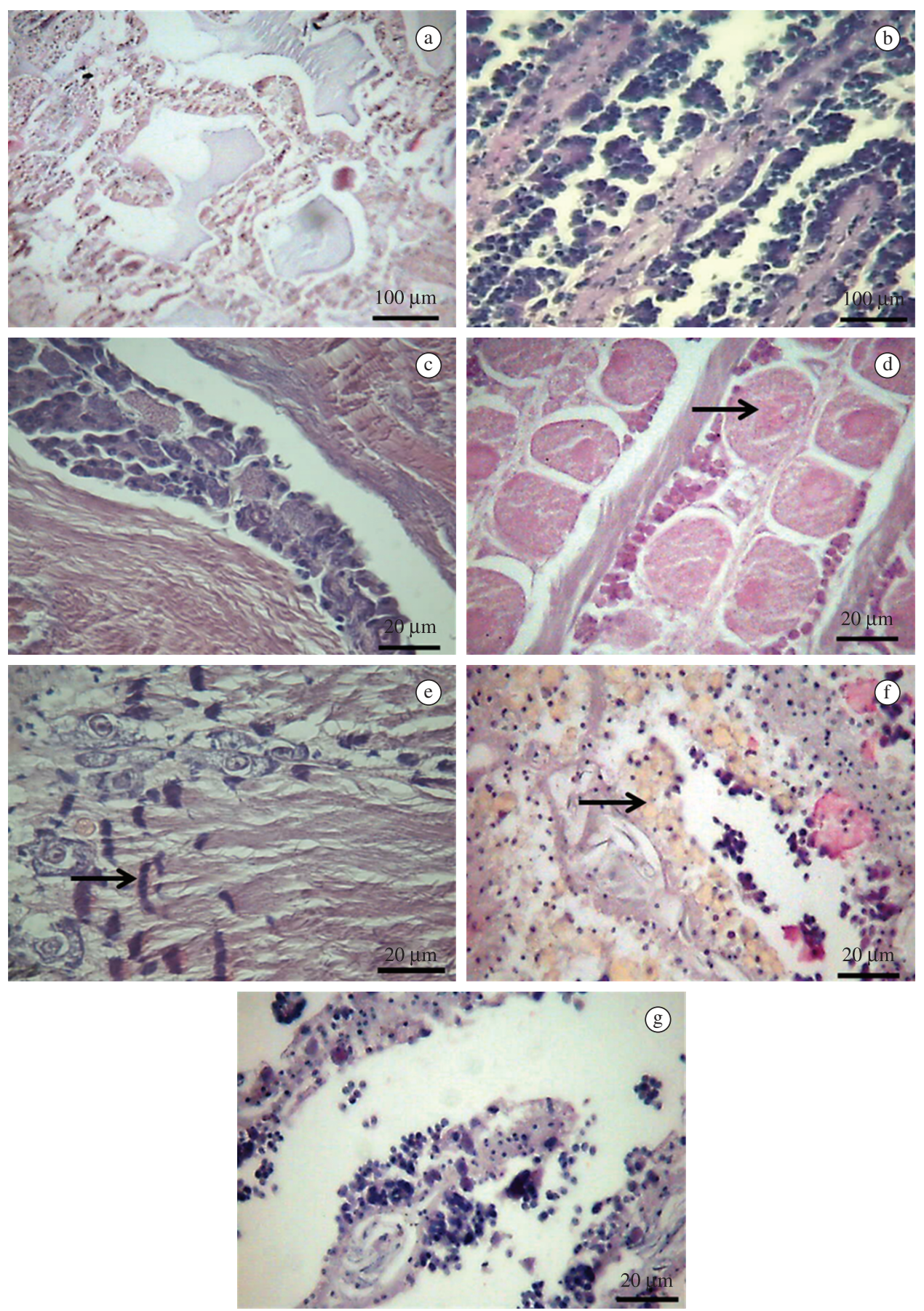

Figure 1. M. coffeus gonad development stages. a) "Resting" stage; b) "Cell Proliferation" stage; c) "Cell Differentiation/ Maturation" stage; d) "Final Maturation/Release" stage, showing mature oocytes; e) "Final Maturation/Release" stage, showing spermatozoids; f) "Final Maturation/Release" stage, showing macrophage cells; and g) "Exhaustion" stage.

The fact that no specimens were found to be in the "Resting" stage between February and May, 2007 and between March and June, 2008 corroborates the chronological framework of the reproductive period described above. In the other months in which the "Final Maturation/Release" stage was predominant, there were few individuals in the
"Resting" stage. These specimens had an average shell height of $8.9 \pm 1.8 \mathrm{~mm}$, possibly corresponding to juveniles who had not started their reproductive activity yet.

Over the months, the percentage of organisms in the "Final Maturation/Release" stage decreased progressively until the end of the climatic period, while the number of 


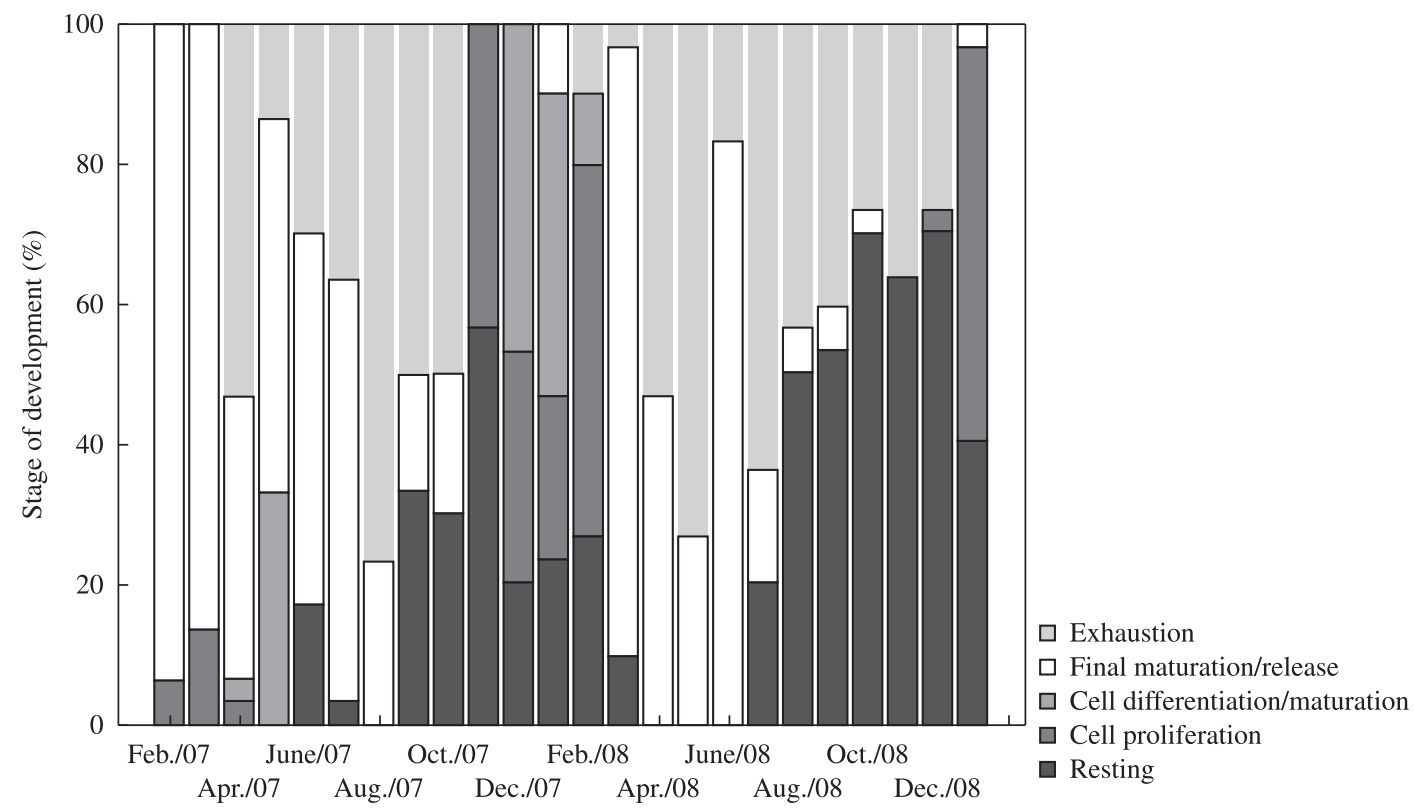

Figure 2. M. coffeus gonad development stages observed between February, 2007 and January, 2009.

individuals in the "Exhaustion" stage increased proportionally. Thus, the months that showed the highest values are those following the reproductive period.

The "Cell Proliferation" and "Cell Differentiation/ Maturation" stages were more significant between the "Final Maturation/Release" stages of the two sampled years, with the highest rates in the months in which no individuals were found to be in this stage. Thus, the greatest proliferation activity was found in February, 2008 (53.3\%) and January, 2009 (56.9\%), while the highest rate of "Cell Differentiation/Maturation" stage individuals occurred in December, 2007 (46.7\%).

The reproductive cycle can also be identified by the increase in the diameter of the female cells. Significant differences were found in the size of sex cells throughout the sampling period $(\mathrm{H}=1865, \mathrm{gl}=3, \mathrm{p}<0.001)$ (Figure 3$)$. According to the multiple comparisons test, we found that the months of February, 2007 and April, 2008 were substantially similar, and that together with February, March and May, 2008, which were also similar between them, showed the highest diameter values. These months correspond to the "Final Maturation/Release" stage. In these months, we have also observed a large number of mature oocytes. It was also noted that in April 2008, despite having high diameter measurements, this parameter was lower than in the next months, when they were almost constant. This indicates that during the "Final Maturation/ Release" stage, when the mature oocytes are released, new elements are already undergoing a maturation process.

No female cells were found in September, 2007, coinciding with the "Exhaustion" stage. However, not all individuals collected in the same month were in the same development stage, and therefore in the other months characterized above as typical for the "Exhaustion" stage, we could obtain a few cells for measurement (about 20 each month), all with a small diameter. Sex cells recorded in the other months showed similar diameters, indicating that there is a proliferation of new elements or cells in early maturation stages throughout the period.

The Spearman correlation analysis results comparing the different gonadal development stages and female germ cells' diameter with shell height, weight and abiotic parameters showed weak correlations between abiotic parameters and gonadal stages. However, we found a strong positive correlation between the diameter of the female cell with rainfall $(r=0.6)$, and a negative correlation with salinity $(\mathrm{r}=-0.5)$. There were also significant correlations between the gonadal development stages "Resting" $(r=-0.7)$ and "Maturation" ( $\mathrm{r}=0.6)$ with the diameter of the female cell.

\subsection{Embryonic development}

The eggs of M. coffeus are embedded in gelatinous masses of irregular spherical shape and are about $2.20 \pm 0.7 \mathrm{~mm}$ in diameter $(n=27)$. These egg masses have a white transparent color and are attached to tree trunks and roots, fallen logs or to the mangrove sediment. Spawned eggs were only found in the field during the rainy season, between January and June. In the laboratory, the eggs were spawned on the sediment and in contact with the sides of the trays used to keep the specimens.

The spawns had 277 to 1,514 spherical eggs arranged in cords, with a length of $111.89 \pm 12.27 \mu \mathrm{m}$ and a width of $76.12 \pm 10.12 \mu \mathrm{m}(\mathrm{n}=200)$. There was no capsule, but an envelope with a single yolk-rich embryo embedded in an albuminous material. The embryonic development occurs within that envelope and lasts seven to twelve days. We identified the following stages of embryonic and larval development: "Egg", "Segmentation" (S1, S2, S3), "Pre-veliger", and "Veliger" (Figure 4). 
Maia, RC., Rocha-Barreira, CA. and Coutinho, R.

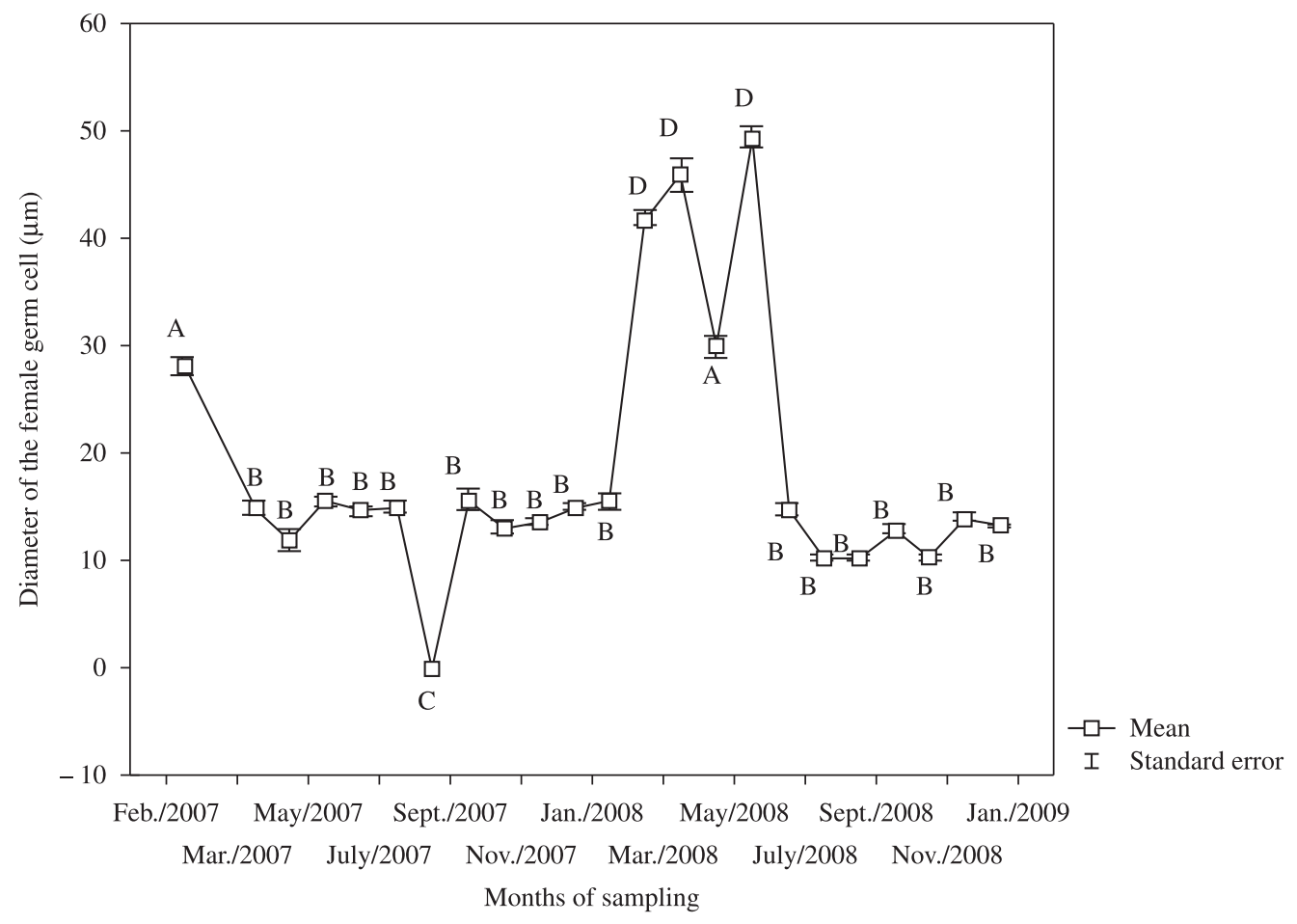

Figure 3. Diameter of the female sex cells throughout the sampled months. Different letters indicate significant differences according to the multiple comparisons test.
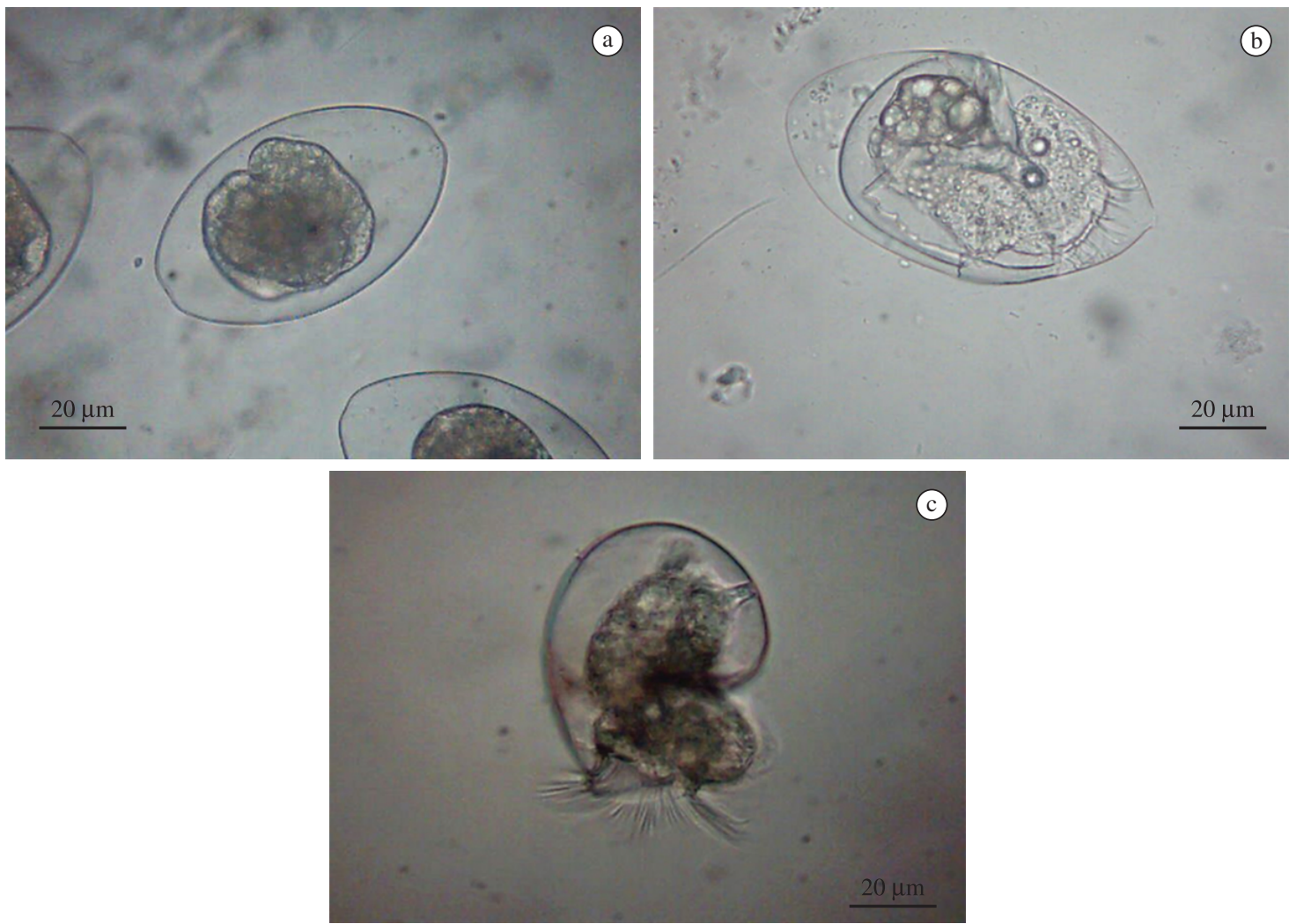

Figure 4. Embryo of M. coffeus in the "Segmentation" stage (a), "Pre-veliger" stage (b) and "Veliger" (c) stage. 
The first changes in the egg occurred on average 24 hours after spawning, beginning with a segmentation lasting four to eight days. The "Segmentation" stage was subdivided into three phases: S1, S2 and S3. The S1 was characterized by the first cleavage and cell divisions, with the embryo having a diameter of $47.3 \pm 5.9 \mathrm{~mm}$. In S2, there was a differentiation of vegetative (macromeres) and animal (micromeres) poles, while the embryo was $49.5 \pm 4.7 \mathrm{~mm}$ in diameter. At S3, we observed the formation of the gastrula, with the emergence of a thin organic matrix on the vegetative pole of the embryo that will give rise to the embryonic shell (proto-shell). At this stage, the embryo measured $71.5 \pm 7.1 \mathrm{~mm}$ in diameter. Contraction movements were seen in the embryo about two days after the onset of the segmentation.

The following stages had distinct larval characteristics. Between five and nine days after the onset of the segmentation, we observed the appearance of the "Pre-veliger" stage, measuring $90.7 \pm 6.34 \mathrm{~mm}$ in diameter $(\mathrm{n}=50)$. At this stage, a thin and transparent globular embryonic shell appeared, together with transient larval structures such as cilia, veil, operculum, statocysts and differentiation of the cephalic region. The embryo begins to make slow rotational movements, contractions and movements of the operculum, and the larval heartbeat was also noted.

The "Veliger" stage appeared after eight to thirteen days and had well developed larval structures (bilobed veil, operculum, statocysts, foot, columellar muscle, larval heart) and a hardened globular proto-shell. The rotational movements become more frequent and rapid, promoted by the ripple of the veil and beats of the cilia. The newly hatched larvae measured $113.4+5.47 \mu \mathrm{m}$.

\section{Discussion}

The results of the histological analysis of the ovotestis show that Melampus coffeus is a simultaneous hermaphrodite due to the concurrent production of male and female gametes in the gonad. Similar results were obtained by Spelke et al. (1995), who considered the simultaneous hermaphroditism to be a common character in this genus. However, Morton (1955a, b) stated in his pioneering studies with this group that all Ellobiidae were protandric. Marcus and Marcus (1965) corroborated these studies and reported that $M$. coffeus is a protandric hermaphrodite, while Apley (1970) and Balboni-Tashiro et al. (1985) indicated that another species of the same genus, M. bidentatus (Say, 1822), is a simultaneous hermaphrodite, yet they did not confirm this fact with histological examinations.

According to Jarne and Auld (2006), simultaneous hermaphroditism paves the way for self-fertilization. However, M. coffeus has two separate palleal gonadal ducts, an anatomical mechanism that prevents it (Martin, 1996b). In this study, the male and female sex cells of M. coffeus were found in the same follicle in an interspersed and radial distribution, as in M. bidentatus (Apley, 1970), another species of the genus, but their maturation occurs at different times. This is possibly a functional mechanism to avoid self-fertilization. Differential reproductive strategies such as these confer selective advantages to these animals, making them one of the most successful groups of mollusks (Morton, 1955a, b). In other hermaphroditic mollusks, when there is a simultaneous production of male and female gametes in the same specimen, these are occasionally released through a common duct, as in Anodontites trapesialis (Lamarck, 1819) (Callil and Mansur, 2007), Megalobulimus abbreviatus (Berquaert, 1948) (Horn et al., 2005), Corbicula fluminea (Müller, 1774) and Corbicula leana (Prime, 1864) (Park and Chung, 2004). The maturation of germ cells in these species occurs simultaneously or within the same follicle in different parts of the visceral mass, or in different, interspersed follicles, thus favoring self-fertilization (Park and Chung, 2004; Horn et al. 2005; Callil and Mansur, 2007).

The comparative analysis between the ovotestis' microscopic and macroscopic morphology in M. coffeus shows a correlation between external features and cellular changes during the reproductive cycle, increasing the size with the increase in the number of oocytes and spermatozoids. The gradual increase of gonad size observed before and during the reproductive period may be the result of the proliferation of gonadal tissue (Rocha-Barreira, 2002) and resembles the data reported by Apley (1970) for $M$. bidentatus. In this species, the volume of the ovotestis tripled during the week preceding the first spawning cycle and steadily decreased after that period.

Based on the frequency analysis of the gonadal development stages, we observed that the species Melampus coffeus has a well-defined synchronous reproductive cycle and successive maturation, spawning and resting periods that can be clearly identified. The names of the gonadal development stages generally follow the criteria established by each particular author, who chooses to emphasize this or that feature. This makes the classification very subjective and the result is a wide variety of classifications which often hamper comparisons between species or even among populations of the same species. Therefore, since there are no reference studies on this group, we decided to use a simplified classification for possible future comparisons, representing the main changes in the reproductive system of $M$. coffeus during its reproductive cycle. Thus, we describe the following gonadal development stages, namely: "Resting", "Cell Proliferation", "Cell Differentiation/ Maturation", "Final Maturation/Release", and "Exhaustion".

The "Cell proliferation" and "Cell Differentiation/ Maturation" stages show the maturation of the animals toward the next reproductive phase, represented by the "Final Maturation/Release" stage. In this study, we surveyed two well-defined annual reproductive periods, from February to July, 2007 and March to July, 2008. After releasing the gametes, there is a resorption of the remaining cellular elements and a gradual decrease in the size of the gonad, featuring the "Exhaustion" stage. The "Resting" stage begins when there are no traces of follicles in the ovotestis. We can see that the reproduction of Melampus occurs in cycles, varying from year to year. The same pattern was 
observed by Apley (1970) for M. bidentatus in American marshes. In that case, the reproductive period occurred between late May and early July, with the events having a correlation with the tides, with about 3 spawning cycles during this period. According to Price (1979), synchrony, cycle length and number of reproductive cycles during the year in Melampus may be specific characteristics of each population or may vary among populations settling different geographical areas.

To obtain more detailed and reliable information regarding the study of the reproductive cycle of the species, the measurement and the counting of oocytes have been used as complementary methods, supported by histological techniques (Callil and Mansur, 2007). Among the studies already conducted on hermaphroditic snails using this method of analysis, we should highlight the research carried out on Megalobulimus abbreviatus by Horn et al. (2005) and on Anodontites trapesialis by Callil and Mansur (2007). The observed variations in the diameter of the female sex cells of $M$. coffeus during the different months of the study were proportional to the gonadal development stages of the species. According to the data obtained in this study, we found that during the "Final Maturation/Release" stage, the measured sex cells had larger diameters and we were able to visualize the mature oocytes.

The size variations observed in these cells during the reproductive period relate to the fact that the maturation of male and female germ cells does not happen simultaneously. As the mature oocytes are released, the diameter of the germ cells decreases as the other female cells present in the ovotestis undergo a process of differentiation or are in their initial maturation stages. A significant amount of spermatozoids are present in the gonad during these periods. In the other sampling months, the diameter values were similar, showing that not all individuals were at the same gonadal development stage, as observed in the analysis of frequencies. Prior studies conducted on hermaphroditic snails also indicated variations in the diameter of the female germ cells which, according to the authors, was due to seasonal variations (Horn et al. 2005; Callil and Mansur, 2007), suggesting that the triggering of the reproductive cycle stages can be induced by environmental variations.

The maturation of the gametes and subsequent spawning of these pulmonate mollusks may be influenced by abiotic factors such as temperature and salinity (Apley, 1970; Price, 1979; Spelke et al., 1995; Ocaña and Emson, 1999; Pechenik et al., 2003). In this study, no significant correlation with the temperature of the studied environment was found but the mean diameter of the oocytes showed a negative correlation with salinity and a positive correlation with rainfall. In the Brazilian northeast, where this study was conducted, temperature changes are not so marked and therefore do not induce different responses in the reproductive cycle of M. coffeus. Similar results were reported by other studies conducted in the region. In these cases, salinity was the factor that exerted the most influence over the reproductive cycle of the studied species, while rainfall had an inversely proportional effect (Rocha-Barreira, 2002; Rocha-Barreira and Araújo, 2005). As noted in previous studies, salinity influences the population dynamics of M. coffeus, leading to differences in the density of snails and shell height; these results are in line with studies performed on M. bidentatus (Fell and Williams, 1985; Burnham and Fell, 1989). Thus, the results indicate that in drought periods, $M$. coffeus populations have a lower density and are composed of large adults. Possibly, smaller individuals cannot withstand high salinity levels and that is why there is no reproductive activity during this season. After that season, when rainfall values increase and the salinity decreases, the populations are very dense and are predominantly composed of small animals due to the reproductive event.

The spawning patterns and the development mode observed in this study were similar to those reported by Marcus and Marcus (1965) for M. coffeus and were in agreement with those reported for other Ellobiidae species. $M$. bidentatus spawning, for instance, is done in gelatinous masses of about 850 eggs, with an embryonic development of approximately 13 days (Apley, 1970). Similar results were reported for Leucophytia, Ovatella and Carychium (Morton, $1955 \mathrm{a}, \mathrm{b}$ ), indicating that this is a common feature of the family. However, further studies are needed to completely elucidate the process, especially regarding the development of the veliger larva to its settlement. This information will help in the understanding of the phylogenetic relationships among pulmonate mollusks and in the conservation of the ecosystems they inhabit.

\section{References}

APLEY, ML., 1970. Field study on life history, gonadal cycle and reproduction periodicity in Melampus bidentatus (Pulmonata: Ellobiidae). Malacologia, vol. 10, p. 381-397.

BALBONI-TASHIRO, JS., WALBORN, P. and CRISE, B., 1985. Diapause, degrowth and fist reproduction in Melampus bidentatus. Biological Bulletin, vol. 169, p. 533.

BURNHAM, BH. and FELL, PE., 1989. Distribution of Melampus bidentatus (Say) and Succinea wilsoni (Lea) within a tidal marsh in eastern Connecticut. The Nautilus, vol. 103, p. 109-112.

CALLIL, CT. and MANSUR, MD., 2007. Gametogênese e dinâmica da reprodução de Anodontites trapesiallis (Lamarck) (Unionoida, Mycetopodidae) no lago Baía do Poço, planície de inundação do rio Cuiabá, Mato Grosso, Brasil. Revista Brasileira de Zoologia, vol. 24, p. 825-840.

FELL, PE. and WILLIAMS, JH., 1985. Distribution of the snail, Melampus bidentatus, and the mussel, Geukensia demissa, along the Pataguanset estuary (Connecticut) in relation to salinity and other tidal marsh invertebrates. The Nautilus, vol. 99, p. 21-28.

HORN, ACM., ACHAVAL, M. and ZANCAN, DM., 2005. The annual reproductive cycle of the snail Megalobulimus abbreviatus (Bequaert, 1948) (Gastropoda, Pulmonata). Brazilian Journal of Biology, vol. 65, p. 459-467. http://dx.doi.org/10.1590/S151969842005000300011 
JARNE, P. and AULD, JR., 2006. Animals mix it up too: The distribution of self-fertilization among hermaphroditic animals. Evolution, vol. 60, p. 1816-1824. PMid:17089966.

KÖPPEN, WP., 1948. Climatologia. Mexico: Fondo de Cultura Economica. 478 p.

MARCUS, E. and MARCUS, E., 1965. On Brazilian supratidal and estuarine snails. Boletim da Faculdade de Filosofia, Ciências e Letras da USP, Zoologia, vol. 25, no. 287, p. 19-82.

MARTINS, AMF., 1996a. Relationships within the Ellobiidae. In TAYLOR, JD. (Ed.). Origin and Evolutionary Radiation of the Mollusca. London: Oxford University Press. p. 285-294.

-, 1996b. Anatomy and systematics of the western Atlantic Ellobiidae (Gastropoda: Pulmonata). Malacologia, vol. 37, p. 163-332.

-, 2001. Ellobiidae - lost between land and sea. Journal of shellfish Research, vol. 20, p. 441-446.

McKEE, KL. and FAULKNER, PL., 2000. Mangrove peat analysis and reconstruction of vegetation history at the Pelican Cays, Belize. Atoll Research Bulletin, vol. 468, p. 46-58.

MOOK, D., 1986. Absorption efficiencies of the intertidal mangrove dwelling mollusk Melampus coffeus and the rocky intertidal mollusk Acanthopleura granulata Gmelin. Marine Ecology, vol. 7, p. 105-113. http://dx.doi.org/10.1111/j.1439-0485.1986.tb00150.x

MORTON, JE., 1955a. The functional morphology of the British Ellobiidae (Gastropoda: Pulmonata) with special references to the digestive and reproductive systems. Biological Sciences, vol. 239, p. 89-160. http://dx.doi.org/10.1098/rstb.1955.0007

,$- 1955 \mathrm{~b}$. The evolution of the Ellobiidae with a discussion on the origin of the Pulmonata. Proceedings of the Zoological Society of London, vol. 125, p. 127-168.

OCAÑA, TM. and EMSON, RH., 1999. Maturation, spawning and development in Siphonaria pectinata Linnaeus (Gastropoda: Pulmonata) at Gibraltar. Journal of Molluscan Studies, vol. 65, p. 185-193. http://dx.doi.org/10.1093/mollus/65.2.185

PARK, G. and CHUNG, E., 2004. Histological studies on hermaphroditism, gametogenesis and cyclic changes in the structures of marsupial gills of the introduced Asiatic clam, Corbicula fluminea and the Korean clam, Corbicula leana. Journal of Shellfish Research, vol. 23, p. 179-184.

PECHENIK, JA., MARSDEN, ID. and PECHENIK, O., 2003. Effects of temperature, salinity and air exposure on the development of the estuarine pulmonate gastropod Amphibola crenata. Journal of Experimental Marine Biology and Ecology, vol. 202, p. 159-176.

PRICE, CH., 1979. Physical factors and neurosecretion in the control of reproduction in Melampus (Mollusca: Pulmonata). The Journal of Experimental Zoology, vol. 207, p. 269-282. http:// dx.doi.org/10.1002/jez.1402070210

PROFFITT, CE. and DEVLIN, DJ., 2005. Grazing by the intertidal gastropod Melampus coffeus greatly increases mangrove leaf litter degradation rates. Marine Ecology Progress Series, vol. 296, p. 209-218. http://dx.doi.org/10.3354/meps296209

PROFFITT, CE., JOHNS, KM., COCHRANE, CB., DEVLIN, DJ., REYNOLDS, TA., PAYNE, DL., JEPPESEN, S., PEEL, DW. and LINDEN, D., 1993. Field and laboratory experiments on the consumption of mangrove leaf litter by the macrodetritivore Melampus coffeus L. (Gastropoda: Pulmonata). Biological Sciences, vol. 56, p. 211-222.

RIOS, EC. 1994. Seashells of Brazil. 2nd ed. Rio Grande: Museu Oceanográfico da FURG. 492 p.

ROCHA-BARREIRA, CA., 2002. Gonad characterization and reproductive cycle of Collisella subrugosa (Gastropoda: Acmaeidae) in northeastern Brazil. Brazilian Journal of Biology, vol. 62, p. 885-895. http://dx.doi.org/10.1590/S1519-69842002000500019

ROCHA-BARREIRA, CA. and ARAÚJO, MLR. 2005. Ciclo reprodutivo de Anomalocardia brasiliana (Gmelin, 1791) (Mollusca, Bivalvia, Veneridae) na Praia do Canto da Barra, Fortim, Ceará, Brasil. Boletim do Instituto de Pesca, vol. 31, p. 9-20.

SPELKE, JA., FELL, PE. and HELVENSTON, LL., 1995. Population structure, growth and fecundity of Melampus bidentatus (Say) from two regions of a tidal marsh complex in Connecticut. The Nautilus, vol. 108, p. 42-47. 
